Комнатний Сергій Олександрович кандидат педагогічних наук, Національна академія внутрішніх справ, Солом'янська площа, 1, Київ, 02000, еmail: komnatniy@ukr.net, тел.: (095) 280-24-80, https://orcid.org/0000-0002-21242047

\title{
ПОНЯТТЯ ТА ФОРМИ СОЦАЛЬНОГО ЖИТЛА У ЖИТЛОВИХ ПОЛІТИКАХ КРАЇН СВІТУ
}

Анотація. Житлове питання було і залишається одним 3 найбільш важливих для людей у всьому світі. Мільйони домогосподарств не мають змоги вирішити проблему відсутності у них житла на ринкових умовах, відтак держави постають перед необхідністю створення механізмів соціального житла для своїх громадян. Фінансові механізми створення соціального житла у різних країнах $є$ доволі диверсифікованими, але спрямовані вони на досягнення однієї мети. Тому виникає потреба наукового опрацювання системи нормативно-правових актів у галузі житлової політики, яка б регулювала форми, зміст і ключові аспекти практичного впровадження житлових політик, спрямованих на створення й використання соціального житла як форми забезпечення житлом громадян, що не можуть вирішити своє житлове питання самостійно, та дослідження їхнього впливу на розвиток і захист житлових прав громадян, переосмислення їхньої філософсько-правової парадигми. У статті зроблено аналіз досвіду розвинених країн регіону Європейської Економічної Комісії Організації Об'єднаних Націй у сфері соціального житла. Наведено основні форми і приклади соціального житла. Проаналізовано керівні принципи, якими керуються держави при розробці державних стратегій в області соціального житла, підходи до реалізації державних та регіональних політик в галузі та методи розподілу такого житла між громадянами, які потребують вирішення житлового питання. Розглянуто форми користування житлом в різних країнах світу шляхом проведення порівняльного аналізу видів житлового фонду у їх сукупному співвідношенні. Недостатність соціального житла в достатній кількості створює нерівності серед людей у всьому світі, навіть в розвинених країнах, що призводить до соціальних сегрегацій та стоїть на заваді сталого розвитку. Тому, вкрай необхідним $є$ вивчення досвіду країн, які досягли зночного прогресу в сфері забезпечення соціальним житлом окремих категорій громадян, які не в змозі вирішити житлове питання користуючись лише ринковими умовами, поширення даного досвіду та наукове 
опрацювання проблеми. Дослідження має на меті проаналізувати чинний стан забезпечення соціальним житлом громадян у провідних країнах та розглянути визначення соціального житла, які застосовуються.

Ключові слова. Житлова політика, соціальне житло, доступне житло, будівництво житла, механізми забезпечення житлом, житловий фонд.

Komnatniy Serhii Oleksandrovych $\mathrm{PhD}$ in Pedagogical Sciences, National Academy of Internal Affairs, Solomianska Square, 1, Kyiv, 02000, e-mail: komnatniy@ukr.net, tel.: (095) 280-24-80, https://orcid.org/0000-0002-2124-2047

\section{CONCEPTS AND FORMS OF SOCIAL HOUSING IN HOUSING POLICIES OF THE WORLD}

Abstract. The housing issue has been and remains one of the most relevant issues for people around the world. Millions of households are unable to solve the problem of lack of housing on market terms. Consequently, countries are faced with the need to create mechanisms for social housing for their citizens. The financial mechanisms for creating social housing in different countries are quite diversified, but they are aimed at achieving one goal. Therefore, there is a need for the scientific study of the system of regulations in the field of housing policy, which would regulate the forms, content and key aspects of practical implementation of housing policies aimed at creating and using social housing as a form of housing for citizens who cannot solve their housing problems, and research of their influence on the development and protection of housing rights of citizens, rethinking their philosophical and legal paradigm. The article analyzes the experience of developed countries in the region of the United Nations Economic Commission for Europe in the field of social housing. The main forms and examples of social housing are given. The guiding principles that direct states in developing state strategies in the field of social housing, approaches to the implementation of state and regional policies in the field and methods of distribution of such housing among citizens in need of housing were analyzed. The forms of housing use in different countries of the world were considered by conducting a comparative analysis of the types of housing stock in their aggregate ratio. Insufficient social housing creates inequalities among people around the world, even in developed countries, leading to social segregation and hampering sustainable development. Therefore, it is essential to study the experience of countries that have made progress in providing social housing for certain categories of citizens who are unable to solve the housing problem using only market conditions, the dissemination of this experience and scientific study of the problem. The study aims to analyze the current state of social housing in leading countries and to consider the definitions of social housing that are used. 
Keywords: housing policy, social housing, affordable housing, housing construction, housing mechanisms, housing fund.

Постановка проблеми. Кожна країна прагне створити сприятливі умови для життя і розвитку своїх громадян. Проблема забезпечення житлом соціально вразливих, незаможних громадян $\epsilon$ глобальною i актуальною навіть для розвинених держав світу. Стрімкий процес урбанізації посилює проблему 3 житлом у великих містах. Реалізація програм соціального житла покликана скоротити нерівність між людьми у забезпеченні природного права кожного на достатній життєвий рівень. В Україні інститут соціального житла фактично відсутній, тому є необхідність вивчення світового досвіду створення житла для окремих категорій громадян і відповідно - формування достатнього фонду доступного соціального житла.

Аналіз останніх досліджень і публікацій. Важливі аспекти формування i реалізації програм соціального житла як механізмів забезпечення громадян доступним житлом досліджувалися такими українськими вченими, як О. Непомнящий, О. Кучеренко, В. Ніколаєв, В. Фатула та іншими.

Мета статті. У статті пропонується дослідити поняття соціального житла, закріплене у житлових політиках держав світу, механізми розподілу такого житла і дійсний стан житлового фонду у країнах регіону Європейської Економічної Комісії Організації Об’єднаних Націй.

Методологічний інструментарій обрано з урахуванням поставленої мети, специфіки предмета і об'єкта дослідження через системний порівняльно-правовий аналіз світової практики у сфері соціального житла, дослідження ефективності чинних форм з урахуванням економічних і правових аспектів.

Виклад основного матеріалу. У багатьох країнах світу, особливо після Другої світової війни, гостро постала проблема забезпечення житлом їхніх громадян і загалом осіб, що мешкають на відповідних територіях. Кожна держава має власні особливості в підходах до формування й реалізації житлової політики. Для України важливими є дослідження і впровадження наукових та практичних підходів держав у питаннях реалізації права кожного індивіда, що відповідає певному визначеному переліку встановлених законом норм, на забезпечення його житлом на території нашої держави. Формування методології і практики застосування системи механізмів різних рівнів державного управління країн світу може відіграти важливу роль у питаннях формування і реалізації житлової політики України [1].

Ідею рівності та рівної гідності людей як одного 3 основних правових принципів висловлював Мартін Лютер (1483-1546). Він вважав, що держава створена для вирішення тих завдань, які не вирішує церква як соціальний інститут [2]. 
Погляди й підходи до формування і реалізації житлової політики та захисту житлових прав громадян у країнах світу різняться, але переважно держави формують свої житлові стратегії і політики, орієнтовані на конкретні умови й результати, яких планується досягти. Майже всі країни, особливо економічно розвинені, надають у тій чи іншій формі підтримку громадянам, які не мають засобів для забезпечення себе мінімальними житловими умовами.

Поняття доступного житла, достатнього житла, достойного житла, соціального житла країни світу трактують по-різному, але повсюди ці поняття в тій чи іншій мірі формують напрямки реалізації політики у сфері захисту базових прав громадян.

Основними викликами на шляху досягнення бажаних результатів у забезпеченні житлових прав громадян, які спостерігаються у майже всіх країнах світу, є потреба в достатньому житлі, що постійно зростає, та недостатній рівень фінансування житлової політики. Процес глобальної урбанізації потребує розробки нових житлових стратегій, спрямованих на створення додаткових житлових об'єктів у містах і недопущення негативних наслідків у сфері захисту довкілля, збереження культурної спадщини, забезпечення достойних i комфортних умов проживання в містах та соціальної сегрегації.

За даними ООН, до 2050 року в містах мешкатимуть дві третини людства, тобто 6,5 мільярдів жителів планети. Це потужний виклик для збереження екосистеми Землі [3].

Загальноприйняті принципи розподілу соціального житла можна розділити на три категорії: універсальна - коли розподіл соціального житла відбувається незалежно від обмежень за рівнем доходів, цільова - розподіл відбувається на підставі встановленого рівня доходів домогосподарства, i залишкова, за якої розподіл житла здійснюється на користь визначених, вразливих або особливих груп.

Дослідження Європейської Економічної Комісії Організації Об’єднаних Націй свідчать, що більшість держав-членів Європейської Економічної Комісії Організації Об’єднаних Націй схильні до залишкової моделі надання соціального житла. Загальна тенденція, що переважає в регіоні після світової фінансової кризи 2008-2009 років, свідчить про підвищення уваги до переоцінки чинних механізмів фінансування і розподілу соціального житла та забезпечення витратоефективності i відповідності трансформаційним тенденціям на ринку. У більшості країн Східного партнерства триває вивчення і апробація нових фінансово-кредитних механізмів забезпечення достатньої кількості доступного соціального житла. Робляться кроки до розвитку державного-приватного партнерства у житловій сфері. Зберігається тенденція і стала практика співпраці 3 міжнародними фінансовими інституціями. 
Відповідно до керівних принципів формування сучасної житлової політики, житло є комплексним продуктом. Доступ до достойного, доступного житла має значення для реалізації інших прав громадянина, а саме права на здоров'я, освіту, роботу. Доступ до достойного житла мінімізує ризики всіх форм сегрегації. Формування політик у сфері соціального житла має чітку взаємодію 3 національними системами надання соціальної допомоги.

Стандарти і підходи до формування й реалізації соціального житла в країнах світу різняться, але їхня сутність має спільні риси і є однією з форм користування житлом для окремих, встановлених національними законодавствами категорій громадян. У будь-якому разі, форма користування житлом пов’язана 3 державною або муніципальною підтримкою. Така підтримка може полягати в пільгових ставках за іпотечними кредитами, пільговій вартості оренди або частковій компенсації вартості житла чи комунальних послуг.

Розглянемо декілька прикладів житлових політик у різних державах в частині визначення поняття і форм соціального житла.

У Австрії відсутнє законодавчо закріплене поняття соціального житла, проте існують різні форми надання житла поза ринком для окремих соціально вразливих категорій громадян.

У Великобританії соціальне житло - це орендне житло з помірною платою для громадян, фінансово не спроможних сплачувати ринкову оренду плату, переважно воно належить муніципалітетам.

У Німеччині є поняття «цільове житло»- це фінансово доступне житло, яке тимчасово субсидується державою.

Соціальне житло у Франції має назву «житло з помірною орендною платою». У Данії «суспільне житло» поділяється на три основні групи за категоріями громадян, для допомоги яким воно призначене: соціальне житло сімейного типу, соціальне житло для перестарілих і соціальне житло для молоді.

У Сполучених Штатах Америки використовується термін «державне житло». Користуються таким житлом сім’ї з низькими доходами і перестарілі.

Поняття соціального житла в Сербії визначене національним законодавством як житло, що надається за підтримки держави відповідно до соціальної та житлової стратегій в межах окремих житлових програм домогосподарствам, які не мають можливості для придбання житла на ринкових умовах.

У законодавстві Фінляндії термін «соціальне житло» визначає субсидовані державою житлові приміщення з регульованою орендною платою.

У законодавстві Чеської Республіки відсутнє визначення терміну «соціальне житло», натомість існує визначення житла для людей, які не в змозі придбати собі житло на вільному ринку. Субсидоване орендне житло призначене для окремих цільових груп. 
Житловий фонд соціального призначення Таджикистану $\epsilon$ сукупністю будівель державного житлового фонду на підставі угоди про соціальну оренду. Як випливає з аналізу визначення поняття соціального житла, в національних законодавствах відсутній єдиний підхід i уніфіковані керівні принципи формування стратегій соціального житла в країнах регіону Європейської Економічної Комісії Організації Об’єднаних Націй.

1998 року Свропейська Федерація соціально-житлового господарства запропонувала таке визначення соціального житла: житло, доступ до якого контролюється наявністю правил розподілу, згідно з яким, пріоритет надається домогосподарствам, що мають складнощі з придбанням житла на ринку. Та це визначення не набуло широкого застосування в міжнародних документах як доволі загальне і таке, що не враховує соціально-культурні та економічно обгрунтовані відмінності між країнами.

Соціальне житло не має єдиного визначення, по суті, воно є ключовим поняттям, яке використовується урядами i зацікавленими сторонами в обміні знаннями в тій частині їхніх житлових систем, яка спрямована на задоволення потреб у житлі, що підтримується державою і надається через адміністративні процеси, характерні для місцевих контекстів [3].

У більшості держав світу соціальне житло - це орендне житло 3 помірною платою, хоча в деяких країнах можлива його купівля або будівництво 3 подальшим набуттям права власності.

У переважній більшості європейських країн застосовується форма соціальної оренди.

В Іспанії, Кіпрі, Греції соціальне житло надається у вигляді здешевленого за державної підтримки житла, яке надходить у продаж для окремих соціальних категорій громадян.

У деяких країнах діють програми підтримки придбання житла у власність через субсидіювання частини іпотечних платежів (Великобританія, Польща, Словаччина). У Сполучених Штатах Америки надаються державні гарантії за іпотечними кредитами окремим категоріям громадян, що створює можливість банкам зменшити розмір першого внеску при наданні іпотечного кредиту.

Деякі держави надають житло на праві користування без застосування поняття оренди та без набуття права власності.

За даними Європейської Федерації соціально-житлового господарства, власниками соціального житла в Європейському Союзі є національні й місцеві органи влади, державні компанії, неприбуткові асоціації, кооперативи, благодійні установи, приватні комерційні забудовники та інвестори.

Одним з поширених видів фінансової підтримки соціального житла в країнах Свропи є субсидії. Субсидії мають завданням як здешевлення вартості 
комунальних послуг (Угорщина), так і субсидіювання будівництва житла з метою здешевлення його вартості для придбання або подальшої здачі в оренду кінцевим споживачам (Іспанія).

Більшість житлових політик країн Європи під соціальним житлом інтерпретують все житло, яке використовується відповідно до встановлених національними законодавствами правил окремими категоріями громадян та надається їм за державної, муніципальної чи іншої підтримки. При цьому неправильним буде твердження, що у всіх державах 3 високою часткою приватного житла є низький рівень соціальної підтримки громадян в доступному житлі. Деякі держави, впроваджуючи практику вільного розвитку житлового сектора на ринкових умовах, передбачають у своїх політиках різні види цільової підтримки тих чи інших категорій громадян. Майже всі країни ухвалюють i реалізовують житлові програми для громадян, які потребують соціального захисту та, відповідно до національного законодавства, мають право на таку підтримку. Житлові політики країн світу формуються державами з урахуванням потреб у житлі, економічних можливостей та соціально культурних чи історичних аспектів. У реалізації житлових політик активну участь відіграють муніципалітети, а в окремих країнах на них покладено основну роль у забезпеченні громадян доступним житлом. Зазвичай у державах чи окремих муніципалітетах створюють уповноважені установи, на які покладено функції реалізації житлових програм. Ці установи ведуть облік громадян які мають право на житлову допомогу, облік житла соціального призначення, за потреби здійснюють залучення фінансування на житлові проекти і безпосередньо реалізують державні чи муніципальні житлові програми.

За даними Європейської Федерації соціально-житлового господарства, власниками соціального житла в Європейському Союзі є національні й місцеві органи влади, державні компанії, неприбуткові асоціації, кооперативи, благодійні установи, приватні комерційні забудовники та інвестори.

Структура форм користування житлом у деяких країнах має такий вигляд [3]:

\begin{tabular}{|l|c|c|c|}
\hline \multicolumn{1}{|c|}{ Країна } & $\begin{array}{c}\text { Приватний } \\
\text { житловий фонд, \% }\end{array}$ & $\begin{array}{c}\text { Приватне орендне } \\
\text { житло, \% }\end{array}$ & $\begin{array}{c}\text { Різні форми } \\
\text { соціального або } \\
\text { доступного житла, } \\
\%\end{array}$ \\
\hline Австрія & 56 & 17 & 27 \\
\hline Азербайджан & 88 & 17 & 23 \\
\hline Албанія & 100 & & 4 \\
\hline Вірменія & 95 & 1 & 21 \\
\hline Білорусія & 77 & 2 & 7 \\
\hline Бельгія & 68 & 25 & 4 \\
\hline Болгарія & 96 & 0 & \\
\hline
\end{tabular}




\begin{tabular}{|c|c|c|c|}
\hline Великобританія & 66 & 16 & 18 \\
\hline Угорщина & 92 & 3 & 4 \\
\hline Німеччина & 42 & 53 & 5 \\
\hline Греція & 74 & 20 & 6 \\
\hline Грузія & 95 & & 5 \\
\hline Данія & 46 & 20 & 34 \\
\hline Ірландія & 79 & 12 & 9 \\
\hline Іспанія & 85 & 11 & 4 \\
\hline Італія & 69 & 14 & 17 \\
\hline Казахстан & 97 & & 3 \\
\hline Канада & 69 & 25 & 6 \\
\hline Кіпр & 68 & 14 & 18 \\
\hline Киргизстан & 97 & & 3 \\
\hline Латвія & 85 & 14 & 1 \\
\hline Литва & 97 & & 3 \\
\hline Люксембург & 70 & 27 & 3 \\
\hline Мальта & 75 & 16 & 8 \\
\hline Молдова & 97 & & 3 \\
\hline Нідерланди & 58 & 10 & 32 \\
\hline Польща & 64 & & 36 \\
\hline Португалія & 75 & 18 & 7 \\
\hline Росія & 86 & 10 & 14 \\
\hline Румунія & 96 & 1 & 3 \\
\hline Сербія & 87 & 11 & 2 \\
\hline Словаччина & 83 & 3 & 14 \\
\hline США & 65 & 32 & 3 \\
\hline Таджикистан & 93 & & 7 \\
\hline Туреччина & 68 & & 32 \\
\hline Узбекистан & 98 & & 2 \\
\hline Україна & 93 & 2 & 5 \\
\hline Фінляндія & 65 & 17 & 18 \\
\hline Франція & 57 & 22 & 31 \\
\hline Хорватія & 89 & 7 & 4 \\
\hline Чехія & 56 & 22 & 22 \\
\hline Швейцарія & 37 & 49 & 14 \\
\hline Швеція & 44 & 35 & 21 \\
\hline Естонія & 82 & 8 & 9 \\
\hline
\end{tabular}

Висновки. Очевидно, що житлові політики різних держав світу $\epsilon$ диверсифікованими, такими, що демонструють різні підходи до формування структури власності та користування житловими фондами. У більшості країн переважає приватна форма користування житлом. Слід відзначити, що у державах Центральної і Східної Свропи чинний показник величини приватного житлового 
фонду досягнуто через реалізацію масштабних програм приватизації житлового фонду. Така ситуація, 3 одного боку, сприяє становленню і вихованню відповідального власника житлового фонду, а 3 іншого - призводить до скорочення житлового фонду соціального призначення, який перебуває в управлінні держави чи муніципалітету для забезпечення належних житлових умов мешкання соціально незахищених верств населення. Принципи і законодавчо врегульовані процеси приватизації житлового фонду не завжди відповідають соціально справедливим i економічно обгрунтованим підходам. Соціально відповідальна держава має вживати всіх можливих заходів для стимулювання формування фонду соціального житла для своїх громадян з метою задоволення їхніх природних прав і запобігання виникненню нерівностей у суспільстві.

\section{Jimepamypa:}

1. Д. Харченко Зарубіжний досвід у сфері державного управління забезпечення прав громадян на житло. http://www.lvivacademy.com/vidavnitstvo_1/edu_49/fail/14.pdf

2. О. Балинська, А. Токарська, В. Ященко. Актуальні проблеми філософії права. Львів. 2017. C.23.

3. Соціальне житло в регіоні ЄК ООН моделі тенденції виклики UNECE 2018.

\section{References:}

1. Kharchenko, D. (2016). Zarubizhnyi dosvid u sferi derzhavnoho upravlinnia zabezpechennia prav hromadian na zhytlo. Efektyvnist derzhavnoho upravlinnia - Efficiency of Public Administration, 4(49)(1), 108-115. Retrievede from http://www.lvivacademy.com/vidavnitstvo_1/edu_49/fail/14.pdf [in Ukrainian].

2. Balynska, O., Tokarska, A., Yashchenko, V. (2017). Aktualni problemy filosofii prava [Current issues of philosophy of law]. Lviv: LvDUVS [in Ukrainian].

3. Sotcialnoe zhile $v$ regione EEK OON. Modeli, tendentcii $i$ vyzovy [Social housing in the UNECE region. Models, trends and challenges]. (2018). New York and Geneva [in Russian]. 